\title{
PERANAN GURU BIMBINGAN KONSELING DALAM MEMOTIVASI PESERTA DIDIK SELAMA MASA PANDEMI COVID-19 DI SMA DARUT TAQWA PASURUAN
}

\author{
Gatut Setiadi1), M. Sholihun'2), Nurma Yuwita ${ }^{3)}$ \\ 1),gatutsetiadi@iaiskjmalang.ac.id, sholihunsmkdt1978@gmail.com²) \\ nurma@yudharta.ac.id3) \\ 1),2)IAI Sunan Kalijogo Malang, ${ }^{2}$ Universitas Yudharta
}

\begin{abstract}
Abstrak. Motivasi belajar menjadi aspek penting guna mencapai tujuan pembelajaran yang telah direncanakan baik itu di dalam sekolah maupun di luar sekolah. Penelitian ini bertujuan untuk mengetahui tindakan guru BK dalam memberikan motivasi belajar terhadap peserta didik di SMA Darut Taqwa selama masa pelaksanaan pembelajaran di rumah akibat dari pandemi COVID-19 di Indonesia. Mewabahnya COVID-19 ini memaksa pihak sekolah harus melaksanakan pembelajaran secara online dikarenakan untuk memutus rantai penularan virus tersebut dan demi keselamatan semua peserta didik. Metode penelitian yang diterapkan yakni deskriptif kualitatif, sedangkan teknik pengumpulan data dilakukan melalui observasi, wawancara, dan dokumentasi. Setelah diperoleh berbagai data yang dibutuhkan, maka semua data valid tersebut dianalisis dengan tahapan reduksi data, hingga dapat dilakukan penyajiaan data dan penarikan kesimpulan. Hasil penelitian ini menunjukkan bahwa peran guru BK untuk memberikan motivasi belajar pada peserta didik dengan cara memberikan pemahaman tentang pentingnya belajar dalam kondisi yang tidak stabil disebabkan karena mewabahnya suatu virus memberikan suatu pengaruh yang signifikan, karena di saat pembelajaran dilaksanakan secara daring peserta didik justru semakin membutuhkan perhatian dan bimbingan lebih intens. Beberapa tindakan yang dilakukan guru BK di SMK Darut Taqwa yakni dengan cara memberikan informasi cara belajar yang efektif terhadap seluruh peserta didik, mulai teknik menghafal, mengorganisasi materi pelajaran secara daring, dan teknik menghadapi ujian online dengan memberikan tips cara meningkatkan kesadaran metakognitif peserta didik.
\end{abstract}

\section{Kata Kunci: Guru BK, Motivasi Belajar, Pandemi COVID-19}

Abstract. Learning motivation becomes an important aspect in achieving planned learning objectives both inside and outside of school. This study aims to determine the actions of $\mathrm{BK}$ teachers in providing motivation to learn towards students in Darut Taqwa High School during the period of learning at home as a result of the COVID-19 pandemic in Indonesia. The outbreak of COVID-19 forced schools to carry out online learning due to break the chain of transmission of the virus and for the safety of all students. The research 


\section{Al-Isurof \\ Jurnal Bimbingan Konseling Islam}

Institut Agama Islam Sunan Kalijogo Malang

P-ISSN 2622-674X / E-ISSN 2721-9585

Volume 2, Nomer 1 / Juni 2020

method applied is descriptive qualitative, while data collection techniques are carried out through observation, interviews, and documentation. After obtaining various data needed, all valid data are analyzed with data reduction stages, so that data can be prepared and conclusions drawn. The results of this study indicate that the role of the BK teacher to provide motivation to learn by giving students an understanding of the importance of learning in unstable conditions due to the outbreak of a virus has a significant effect, because when learning is carried out online the students actually need it even more more intense attention and guidance. Some of the actions taken by the BK teacher at Darut Taqwa Vocational School are by providing information on effective learning for all students, starting with memorization techniques, organizing subject matter online, and dealing with online exams techniques by providing tips on how to increase students' metacognitive awareness.

Keywords: BK Teacher, Learning Motivation, COVID-19 Pandemic

\section{A. PENDAHULUAN}

SMA Darut Taqwa merupakan salah satu lembaga pendidikan yang berada dalam naungan Pondok Pesantren Ngalah Pasuruan. Proses pendidikan di sekolah ini menerapkan berbagai kerjasama dalam lingkungan sekolah untuk menciptakan suasana kondusif dalam pembelajaran. Maka itu banyak sekali berbagai aspek yang berperan dalam pelaksanaan kegiatan pembelajaran, mulai dari penerapan kurikulum sampai dengan pelayanan individual siswa. Diantara semuanya, salah satu aspek yang berperan penting dalam pelayanan siswa adalah guru pembimbing atau konselor. Menurut Mulyadi guru pembimbing atau konselor sekolah adalah seseorang yang bertanggung jawab memberikan bimbingan dan konseling di sekolah atau madrasah secara sadar terhadap perkembangan kepribadian dan kemampuan yang dimiliki oleh peserta didik ${ }^{1}$. Sedangkan Bimbingan dan konseling merupakan proses pemberian bantuan dari konselor kepada klien secara bertatap muka untuk membantu klien keluar dari masalahnya, dengan adanya bimbingan dan konseling di sekolah diharapkan dapat membantu peserta didik untuk mengaktualisasikan diri yang

${ }^{1}$ Ramayulis, dan Mulyadi. Bimbingan dan Konseling Islam. (Jakarta: Kalam Mulia, 2016). hal. 276. 


\section{Al-Isyrof \\ Jurnal Bimbingan Konseling Islam}

Institut Agama Islam Sunan Kalijogo Malang

P-ISSN 2622-674X / E-ISSN 2721-9585

Volume 2, Nomer 1 / Juni 2020

dimiliki peserta didik secara optimal sehingga dapat tercapai prestasi yang lebih baik. ${ }^{2}$ Jadi agar dapat mengembangkan dan mewujudkan berbagai potensi yang dimiliki oleh siswa di SMA Darut Taqwa, maka peranan guru bimbingan dan konseling sangat dibutuhkan untuk memberikan pelayanan dalam mengembangkan, pembinaan dan pemecahan masalah bagi setiap siswa. Pelayanan yang diberikan guru bimbingan dan konseling kepada siswa diimplementasikan melalui pelayanan bimbingan secara individual atau kelompok yang bertujuan agar mampu memahami perkembangan kehidupan siswa di sekolah maupun luar sekolah dalam rangka mewujudkan cita-cita sesuai dengan kemampuan yang dimiliki oleh mereka, selain itu juga agar tiap siswa secara mandiri mampu memecahkan berbagai kesulitan yang dihadapinya.

Dalam melaksanakan pelayanan bimbingan dan konseling di SMA Darut Taqwa menerapkan pola 17 plus yang terdiri dari enam bidang bimbingan yaitu 1) bidang pribadi, 2) sosial, 3) belajar, 4) karir, 5) berkeluarga dan 6) keberagaman. Sedangkan Sembilan jenis layanan yaitu: 1) orientasi, 2) informasi, 3) penyaluran, 4) pembelajaran, 5) konseling perorangan, 6) konseling kelompok, 7) bimbingan kelompok, 8) konsultasi dan 9) mediasi.

Menyebarnya pandemi virus Covid-19 secara langsung berdampak pada pelaksanaan proses pembelajaran di SMA Darut Taqwa, sehingga menimbulkan berbagai permasalahan siswa di SMA Darut Taqwa yang semakin beragam, berbagai upaya dilaksanakan BK untuk mencegah terjadinya anak malas sekolah karena kurangnya motivasi belajar disebabkan pembelajaran secara daring yang tentu saja sangat berbeda proses pembelajarannya ketika dilaksanakan secara luring. Oleh sebab itu maka peran guru BK sangat dibutuhkan guna menyelesaikan semua permasalahan siswa sehingga dapat meningkatkan motivasi serta kemauan siswa dalam melaksanakan proses belajar di sekolah. Selain itu dalam proses kegiatan pembelajaran di sekolah, guru menghadapi berbagai karakteristik siswa yang sangat

${ }^{2}$ S. Winkel, W. (2006). Bimbingan dan Konseling Di Instituti Pendidikan, Yogyakarta: Media Abadi. Hal.68. 


\section{Al-Isyrof \\ Jurnal Bimbingan Konseling Islam}

Institut Agama Islam Sunan Kalijogo Malang

P-ISSN 2622-674X / E-ISSN 2721-9585

Volume 2, Nomer 1 / Juni 2020

beragam. Ada siswa yang dapat melakukan semua kegiatan belajarnya secara lancar dan berhasil tanpa mengalami kesulitan, namun ada pula sebagian siswa yang justru menghadapi berbagai kesulitan dalam melaksanakan proses pembelajaran, hal ini dapat diketahui dengan tingkat hasil belajar siswa di sekolah. Oleh sebab itu pemberian motivasi dalam belajar sangatlah penting guna memberikan dukungan secara mental kepada siswa agar tetap selalu optimis dan berkembang menjadi lebih baik meskipun melaksankan pembelajaran secara daring.

Belajar merupakan penguasaan materi ilmu pengetahuan yang merupakan sebagian kegiatan menuju terbentuknya kepribadian seutuhnya ${ }^{3}$. Sedangkan menurut Uno, motivasi adalah suatu usaha yang didasari untuk menggerakkan, mengarahkan dan menjaga tingkah laku seseorang untuk bertindak melakukan sesuatu sehingga mencapai hasil atau tujuan tertentu ${ }^{4}$. Berdasarkan pengertian tersebut dapat disimpulkan bahwa motivasi belajar adalah kecenderungan siswa dalam melakukan kegiatan belajar yang didorong oleh kemauan keras untuk mencapai prestasi dan hasil belajar sebaik mungkin. Maka itu dalam proses belajar dibutuhkan adanya motivasi yang akan mendorong individu untuk melakukan suatu pekerjaan. Sebab setiap individu pasti memiliki motivasi yang meliputi kecenderungan mengerjakan tugastugas yang menantang namun tidak berada di atas kemampuannya, keinginan untuk berusaha dan bekerja sendiri serta menemukan penyelesaian sendiri, keinginan kuat untuk maju dan mencapai taraf keberhasilan yang semakin berkembang dengan berorientasi pada masa depan, serta keuletan dalam bekerja. Dengan dimilikinya motivasi belajar untuk setiap siswa, maka akan mampu menguatkan semangat siswa dalam melaksanakan proses belajar, sehingga dapat mengembangkan wawasan dan keterampilan siswa pada bidang ilmu yang ia minati.

Ada dua faktor yang dapat mempengaruhi motivasi belajar siswa yaitu, 1) faktor intrinsik dan 2) faktor ekstrinsik. Faktor intrinsik adalah energi yang menjadi aktif

${ }^{3}$ A.M, Sardiman. (2007). Interaksi dan Motivasi Belajar Mengajar, Jakarta:PT Raja Grafindo Persada. Hlm. 72

${ }^{4}$ Uno, Hamzah B. (2011). Teori Motivasi \& Pengukurannya. Jakarta:PT. Bumi Aksara. Hlm. 43 


\section{Al-Isyrof \\ Jurnal Bimbingan Konseling Islam}

Institut Agama Islam Sunan Kalijogo Malang

P-ISSN 2622-674X / E-ISSN 2721-9585

Volume 2, Nomer 1 / Juni 2020

tanpa memerlukan rangsangan dari luar, karena dalam setiap individu sudah memiliki dorongan untuk melakukan sesuatu. Sedangkan faktor ekstrinsik merupakan energi yang dapat aktif ketika mendapatkan rangsangan dari luar, seperti yang dilakukan guru untuk meningkatkan motivasi belajar siswa. ${ }^{5}$

Berdasarkan hasil wawancara yang dilakukan dengan guru BK, diketahui bentuk permasalahan yang ditemukan di SMA Darut Taqwa menunjukkan adanya beberapa siswa yang memiliki motivasi belajar masih kurang baik, yakni seperti: 1) anak mengulur-ngulur waktu saat pengumpulan tugas, 2) bosan saat mengikuti pelajaran daring, 3) mudah menyerah saat mengalami kesulitan belajar daring, 4) sering ijin keluar saat jam pelajaran berlangsung, 5) dan berdandan ketika pelajaran daring.

Beberapa permasalahan tersebut jika terus diabaikan akan dapat menghambat proses pembelajaran pada diri siswa, maka mencegah berbagai permasalahan tersebut diperlukan perhatian dari guru yang bersangkutan, khususnya guru bimbingan dan konseling. Peran guru bimbingan dan konseling sangatlah penting guna menyelesaikan dan memberikan solusi terhadap permasalah yang sedang dihadapi siswa, agar dapat mengembangkan motivasi belajar siswa sehingga siswa dapat mencapai tujuan yang diinginkan. Agar mendapatkan hasil yang maksimal maka dilakukan kerjasama antara guru bimbingan dan konseling dengan guru mata pelajaran serta wali kelas.

\section{B. METODE PENELITIAN}

Penelitian ini berfokus pada peran guru bimbingan dan konseling dalam mengembangkan motivasi belajar siswa ketika pelaksanaan proses pembelajaran daring, maka jenis penelitian ini menggunakan penelitian deskriptif kualitatif. Penelitian kualitatif merupakan penelitian yang mengamati langsung objek yang diteliti. ${ }^{6}$ Sedangkan menurut Furchhan, penelitian kualitatif merupakan penelitian yang menghasilkan data deskriptif berupa tulisan, ucapan, atau perilaku yang dapat

5 A.M, Sardiman. (2007). Interaksi dan Motivasi Belajar Mengajar, Op.Cit., hlm. 90-91.

${ }^{6}$ Sugiyono. (2016). Metode Penelitian Kuantitatif, Kualitatif, dan R\&D, Bandung: Alfabeta. hlm.9. 


\section{Al-Isurof \\ Jurnal Bimbingan Konseling Islam}

Institut Agama Islam Sunan Kalijogo Malang

P-ISSN 2622-674X / E-ISSN 2721-9585

Volume 2, Nomer 1 / Juni 2020

diamati dari orang yang dijadikan subjek itu sendiri7. Dalam penelitian ini, teknik yang digunakan untuk mengambil sampel adalah purposive sampling. Purposive sampling adalah teknik pengambilan sampel sumber data dengan pertimbangan tertentu, seperti orang tersebut yang dianggap paling tahu tentang apa yang kita harapkan. ${ }^{8}$ Jadi sampel diambil tidak secara acak tetapi ditentukan oleh peneliti, pada penerapan purposive sampling ini peneliti menentukan guru BK, guru mata pelajaran dan guru wali kelas di SMA Darut Taqwa sebagai orang yang memahami berbagai permasalahan dan solusi untuk siswa. Tetapi fokus utama dalam penelitian ini yakni kepada guru BK yang memiliki peranan utama dalam membimbing siswa ketika menghadapi permaslahan.

Peran peneliti dalam menemukan data yakni secara partisipasioner, yakni peneliti secara langsung juga menjadi pengajar di sekolah tersebut. Penelitian ini dilaksanakan selama lima bulan dengan mengevaluasi pelaksanaan pembelajaran ketika pelaksanaan pembelajaran daring yang terpaksa dilakukan karena terjadinya pandemi Covid-19. Maka teknik pengumpulan data pada penelitian ini adalah metode observasi, wawancara, dan dokumentasi. Observasi adalah mengamati dengan melakukan pencatatan atas kejadian-kejadian yang dilakukan oleh sumber data. Adapun beberapa jenis observasi yang bisa digunakan, yaitu: 1) observasi partisipatif, 2) obsevasi terus terang atau tersamarkan dan 3) observasi tak berstruktur. ${ }^{9}$ Tetapi dalam penelitian ini hanya menggunakan observasi partisipasi, yaitu peneliti datang langsung ke tempat yang akan diamati yakni SMA Darut Taqwa Pasuruan, dan juga ikut melakukan proses pembelajaran daring untuk memperoleh berbagai data yang valid dan dibutuhkan dalam penelitian.

Sedangkan teknik wawancara merupakan pertemuan dua orang untuk bertukar informasi dan ide melalui tanya jawab, wawancara dalam penelitian ini adalah wawancara bebas terpimpin yang artinya pertanyaan bebas namun sesuai dengan data

${ }^{7}$ Furchan, Arif. (2005). Pengantar Penelitian dalam Pendidikan. Yogyakarta: Pustaka Pelajar.21.

8 Ibid. Hlm.218-2019

${ }^{9}$ Sugiyono. Op.Cit. hlm.227-231. 


\section{Al-Isurof \\ Jurnal Bimbingan Konseling Islam}

Institut Agama Islam Sunan Kalijogo Malang

P-ISSN 2622-674X / E-ISSN 2721-9585

Volume 2, Nomer 1 / Juni 2020

yang akan diteliti. ${ }^{10}$ Objek wawancara pada penelitian ini yakni melibatkan guru BK, guru mata pelajaran dan wali kelas.

Agar mendapatkan data yang akurat maka dilaksanakan juga dokumentasi data, dokumentasi merupakan catatan peristiwa yang sudah berlalu. Dokumentasi ini bisa dalam bentuk tulisan, gambar, atau karya-karya monumental dari seseorang ${ }^{11}$ Berbagai data dokumentasi dalam penelitian ini didapatkan dari arsip dan dokumendokumen program bimbingan dan konseling yang ada di SMA Darut Taqwa.

Semua data yang telah diperoleh dianalisis untuk mendapatkan keakurasian data yang dibutuhkan. Teknik analisis data merupakan proses mencari dan menyusun data secara sistematis berdasarkan semua data yang diperoleh dari hasil wawancara, catatan lapangan, dan bahan-bahan lain, sehingga data-data tersebut dapat mudah dipahami dan hasil temuan dalam penelitian dapat diinformasikan kepada orang lain. Teknik analisis data yang digunakan dalam penelitian ini adalah non statistik yakni analisis data deskriptif, dengan cara melalui proses reduksi data, penyajiaan data dan penarikan kesimpulan. Reduksi data adalah merangkum, memilih hal-hal yang pokok, memfokuskan pada hal-hal yang penting, guna menemukan data yang benar-benar valid. Penyajian data merupakan sekumpulan informasi dari reduksi data yang kemudian disusun agar sistematis dan dapat mudah dipahami. Sedangkan penarikan kesimpulan merupakan temuan baru yang sebelumnya belum pernah ada dan bisa dijadikan acuan untuk hasil penelitian.

\section{KERANGKA TEORITIK}

\section{Motivasi Belajar}

Motivasi berasal secara etimologi berasal dari kata motif diartika sebagai daya upaya yang mendorong seseorang untuk melakukan sesuatu ${ }^{12}$. Berawal dari kata motif

10 Ibid.

11 A. Black, James \& Dean J. Champion. (2009). Methodes And Issues In Social Research. Terj. E. Koswara, Dira Salam dan Alfin Ruzhendri. Bandung: Rafika Adiatama. Hlm.244-253.

12 A.M, Sardiman. (2007). Interaksi dan Motivasi Belajar Mengajar, Jakarta: PT Raja Grafindo Persada. Hlm.37 


\section{Al-Isyrof \\ Jurnal Bimbingan Konseling Islam}

Institut Agama Islam Sunan Kalijogo Malang

P-ISSN 2622-674X / E-ISSN 2721-9585

Volume 2, Nomer 1 / Juni 2020

itu, maka motivasi dapat diartikan sebagai daya penggerak untuk mendorong seseorang mencapai sesuatu hal yang diinginkan. Motivasi sebagai proses yang menjelaskan intensitas, arahan dan ketekunan usaha untuk mencapai suatu tujuan (W. S Winkel, 2008:45). Sedangkan menurut Mc Donald (dalam Sardiman, 2008:73) motivasi adalah perubahan energi dalam diri seseorang yang ditandai dengan munculnya feeling dan didahului dengan tanggapan terhadap adanya tujuan. Motivasi dapat juga dikatakan serangkaian usaha untuk mencapai tujuan yang diinginkan, sehingga seseorang mau dan ingin melakukan sesuatu. Motivasi dapat berfungsi sebagai pendorong usaha dan pencapaian prestasi, seseorang yang melakukan sesuatu usaha karena adanya motivasi. Adanya motivasi yang baik dalam belajar akan menunjukkan hasil yang baik, jadi dengan adanya usaha yang tekun dan didasari adanya motivasi membuat seseorang yang belajar akan dapat mencapai prestasi yang baik.

Belajar merupakan perubahan tingkat laku atau penampilan dengan serangkaian kegiatan. Belajar dapat juga diartikan penambahan pengetahuan. ${ }^{13}$ Oleh karena itu, dapat dikatakan terjadinya proses belajar, apabila seseorang menunjukkan tingkah laku yang berbeda. Proses dalam belajar sangat diperlukan adanya motivasi, agar dapat berhasil dalam pelajaran. Jadi motivasi akan menentukan intensitas usaha belajar bagi para siswa. Menurut W. S. Winkel (1996:92) motivasi belajar dapat diartikan sebagai keseluruhan daya penggerak psikis dalam diri siswa yang menimbulkan kegiatan belajar, memberikan arahan pada kegiatan belajar demi mencapai tujuan. Jadi dapat disimpulkan bahwa motivasi belajar adalah dorongan dalam diri seseorang untuk melakukan sesuatu yang diinginkan dan akan melakukannya agar dapat mencapai sesuatu yang diharapkan. 14

Motivasi belajar dapat dipengaruhi oleh faktor instrinsik dan ekstrinsik. Faktor instrinsik merupakan energi yang menjadi aktif tanpa memerlukan rangsangan dari

13 Ibid. hlm.19-21

${ }^{14}$ S. Winkel, W. (2006). Bimbingan dan Konseling Di Instituti Pendidikan, Yogyakarta:Media Abadi. Hlm.92. 


\section{Al-Isyrof \\ Jurnal Bimbingan Konseling Islam}

Institut Agama Islam Sunan Kalijogo Malang

P-ISSN 2622-674X / E-ISSN 2721-9585

Volume 2, Nomer 1 / Juni 2020

luar, karena dalam diri setiap individu sudah ada dorongan untuk melakukan sesuatu. Adapun faktor instrinsik yang mempengaruhi motivasi belajar siswa adalah, sebagai berikut:

a) Tingkat kecerdasan siswa

merupakan kemampuan psiko-fisik untuk mereaksi rangsangan atau menyesuaikan diri dengan lingkungan dengan cara yang tepat.

b) Sikap siswa

Dapat diartikan sebagai kecenderungan merespon hal-hal positif yang disampaikan guru mata pelajaran.

c) Bakat siswa

Memiliki arti yakni kemapuan potensial yang dimiliki seseorang untuk mencapai keberhasilan pada masa yang akan datang.

d) Minat siswa

adalah kecenderungan atau keinginan yang besar terhadap sesuatu.

e) Motivasi siswa

Merupakan suatu keadaan dari diri siswa yang dapat mendorok dalam melakukan tindakan belajar.

Sedangkan faktor ekstrinsik merupakan motif yang aktif dan berfungsi karena adanya perangsang dari luar. Faktor ini juga penting, karena keadaan siswa itu dinamis, berubahubah dan kemungkinan komponen lain dalam proses belajar mengajar ada yang kurang menarik bagi siswa, maka diperlukan faktor ekstrinsik. Motivasi Ekstrinsik dapat disimpulkan yaitu dorongan yang berasal dari luar diri individu untuk melakukan sesuatu, seperti mengharap pujian, hadiah dan lain sebagainya. Motivasi ini sangat bermanfaat untuk individu yang membutuhkan rangsangan dari luar dirinya untuk mendorong individu melakukan sesuatu.

Untuk menumbuhkan motivasi belajar pada siswa, terdapat beberapa cara sebagai berikut:

a) Memberi angka

Angka dalam hal ini yaitu memberikan nilai dalam kegiatan belajarnya. 


\section{Al-Isurof \\ Jurnal Bimbingan Konseling Islam}

Institut Agama Islam Sunan Kalijogo Malang

P-ISSN 2622-674X / E-ISSN 2721-9585

Volume 2, Nomer 1 / Juni 2020

b) Hadiah

Hadiah dapat membangkitkan semangat seseorang untuk mencapai apa yang diinginkan.

c) Saingan atau kompetisi

Dalam persaingan ini dapat meningkatkan motivasi siswa agar dapat meningkatkan prestasi belajar

d) Memberi ulangan

Memberikan ulangan adalah sarana motivasi untuk siswa agar mengulang kembali materi yang telah diajarkan, dengan begitu akan meningkatkan daya ingat siswa terhadap materi pembelajaran tersebut.

e) Mengetahui hasil

Memberikan asesment kepada siswa dapat menjadi evaluasi bagi siswa, karena dengan mengetahui hasil belajarnya, maka siswa akan lebih bersemangat lagi untuk memperoleh hasil yang lebih baik.

f) Pujian

Pujian ini sebagai reinforcement yang positif yang merupakan motivasi yang baik bagi perkembangan mental siswa, dan kepercayaan diri dalam melaksanakan pembelajaran.

g) Hukuman

Sebagai reinforcement jika diberikan secara baik, tepat dan bijak bisa menjadi alat untuk motivasi siswa, mereka akan menyadari kesalahan yang telah mereka perbuat.

h) Hasrat untuk belajar berarti memiliki keinginankuat untuk belajar dari diri individu setiap siswa.

i) Minat

Minat merupakan rasa menyukai atau menginginkan suatu pengetahuan atau keterampilan jika diartikan dalam ruang lingkup pendidikan. Proses pembelajaran akan berjalan lancar kalau jika muncul adanya minat dalam diri siswa terhadap sesuatu yang akan dipelajarinya. 


\section{Al-Isyrof \\ Jurnal Bimbingan Konseling Islam}

Institut Agama Islam Sunan Kalijogo Malang

P-ISSN 2622-674X / E-ISSN 2721-9585

Volume 2, Nomer 1 / Juni 2020

j) Tujuan yang diakui

Tujuan pembelajaran menjadi target akhir dari sebuah pembelajaran. Dengan memahami tujuan yang ingin dicapai, maka akan memunculkan upaya untuk terus belajar hingga mendapat hasil maksimal berdasarkan tujuan yang telah ditetapkan. ${ }^{15}$

Adapun seseorang yang memiliki kriterian motivasi rendah menurut Atkinson dan Feather adalah, sebagai berikut:

1) Individu yang termotivasi oleh ketakutan dan kegagalan

2) Individu tidak memikirkan akan meraih kesuksesan dari apa yang dilakukan, tetapi lebih fokus akan mendapatkan kegagalan

3) Dalam melakukan tugas, individu memilih melakukan tugas yang mudah sehingga akan terhindar dari kegagalan.

\section{Pengertian Guru Bimbingan dan Konseling}

Guru bimbingan dan konseling merupakan seorang pendidik yang memiliki tugas membantu siswa dalam mengatasi masalah yang sedang dialami siswa di lingkungan sekolah maupun di luar lingkungan sekolah. Guru bimbingan dan konseling bertanggung jawab untuk membantu siswa menyadari kekuatan-kekuatan mereka sendiri, menemukan apa yang merintangi dari permasalahan yang sedang dihadapi seperti apa yang mereka harapkan. Menurut Juantika, peran guru bimbingan dan konseling adalah seorang dengan rangkaian untuk membantu mengatasi hambatan dan kesulitan yang dihadapi peserta didik dalam belajar, pesesuaian dengan lingkungan pendidikan, masyarakat maupun lingkungan kerja. ${ }^{16}$ Dari penjelasan diatas dapat disimpulkan bahwa peran guru bimbingn dan konseling adalah bertanggung jawab untuk membantu siswa mengatasi masalah dengan melaksanakan kegiatan bimbingan dan konseling.

15 A.M, Sardiman. (2007). Interaksi dan Motivasi Belajar Mengajar, Jakarta:PT Raja Grafindo Persada. Hlm.91-95

16 Juntika, Ahmad. (2006). Bimbingan dan Konseling dalam Berbagai Latar Kehidupan. Bandung: PT. Ravika Aditama.hlm.126. 


\section{Al-Isurof \\ Jurnal Bimbingan Konseling Islam}

Institut Agama Islam Sunan Kalijogo Malang

P-ISSN 2622-674X / E-ISSN 2721-9585

Volume 2, Nomer 1 / Juni 2020

Konselor memiliki lima peran genetik, yaitu: sebagai konselor, sebagai konsultan, sebagai agen pengubah, sebagai agen prevensi primer, dan sebagai manajer (Namora Lumongga Lubis, 2011:32). Selain itu, tugas dan peran konselor sebagai berikut (Ramayulis dan Mulyadi, 2016:286):17

a) Membuat catatan mengenai peserta didik untuk dipelajari

b) Guru pembimbing harus mendapatkan kepercayaan dari individu yang bersangkutan

c) Guru pembimbing harus menjelaskan masalah-masalah yang dihadapi terutama kesulitan di sekolah

d) Guru pembimbing harus memimpin dan memberikan saran-saran pemecahan masalah yang positif

e) Guru pembimbing harus membesarkan hati individu agar ia melakukan rencana kegiatan yang telah ditetapkan sebanyak mungkin

f) Guru pembimbing harus mencatat isi wawancara serta hasil yang telah didapatkan

g) Guru pembimbing memberikan bimbingan yang diperlukan sehingga individu dapat melaksanakan berbagai kegiatan atau usaha yang sesuai dengan kemampuan dan masalah yang dihadapi

h) Apabila kegiatan yang telah dilaksanakan itu gagal mencapai sasaran, maka guru pembimbing harus memberikan layanan

Proses bimbingan dan konseling dapat berhasil, apabila mempunyai tujuan yang jelas untuk dicapai. Adapun tujuan bimbingan dan konseling adalah, sebagai berikut: 18

1) Memahami diri, yaitu peserta didik diarahkan untuk mampu memahami dirinya sendiri, terutama memahami kemampuan yang dimiliki.

2) Menyesuaikan diri, yaitu peserta didik diarahkan untuk mampu menyesuaikan diri dengan lingkungan, baik lingkungan keluarga maupun masyarakat.

17 Ramayulis dan Mulyadi. (2016). Bimbingan dan Konseling Islam. Jakarta: Kalam Mulia.hlm.286.

18 Slameto. (2010). Belajar dan Faktor-Fakror yang Mempengaruhinya. Jakarta: Rineka Cipta.hlm.221. 


\section{Al-Isurof \\ Jurnal Bimbingan Konseling Islam}

Institut Agama Islam Sunan Kalijogo Malang

P-ISSN 2622-674X / E-ISSN 2721-9585

Volume 2, Nomer 1 / Juni 2020

3) Mengembangkan diri, yaitu peserta didik diarahkan untuk mampu mengembangkan kemampuan yang dimiliki secara optimal.

Adapun fungsi dari bimbingan dan konseling adalah, sebagai berikut: ${ }^{19}$

1) Fungsi Pencegahan

Untuk mencegah timbulnya masalah pada diri siswa sehingga seseorang dapat terhindar dari berbagai masalah yang menghambat perkembangannya

2) Fungsi Pemahaman

Pembimbing akan memberikan pemahaman tentang diri klien tentang permasalahan yang dihadapi oleh klien

3) Fungsi Penentasan

Upaya yang dilakukan untuk penentasan permasalahan akan dilakukan melalui pelayanan bimbingan dan konseling.

4) Fungsi Pemeliharaan

Memelihara segala sesuatu yang positif pada diri klien, baik yang merupakan bawaan maupun hasil perkembangan yang telah dicapai.

5) Fungsi Penyaluran

Memberikan bantuan menyalurkan kegiatan pada masing-masing siswa melalui pelayanan bimbingan dan konseling.

6) Fungsi Pengembangan

Dalam fungsi pengembangan ini, hal-hal yang positif pada diri siswa tetap dijaga, dimntapkan dan dikembangkan.

7) Fungsi Perbaikan

Individu yang mempunyai masalah akan diprioritaskan mendapat bantuan agar diharapkan masalah yang sedang dihadapi tidak akan terjadi lagi pada masa yang mendatang.

8) Fungsi Advokasi

19 Tohirin, Bimbingan dan Konseling di Sekolah dan di Madrasah. Jakarta: PT Raja Grapindo Persada. Hlm.50. 


\section{Al-Isurof \\ Jurnal Bimbingan Konseling Islam \\ Institut Agama Islam Sunan Kalijogo Malang \\ P-ISSN 2622-674X / E-ISSN 2721-9585 \\ Volume 2, Nomer 1 / Juni 2020}

Membantu individu untuk memperoleh pembelaan atas hak dan kepentingan yang kurang mendapat perhatian.

\section{HASIL PENELITIAN DAN PEMBAHASAN}

SMA Darut Taqwa Pasuruan merupakan lembaga pendidikan formal yang berada dalam naungan pondok pesantren Darut Taqwa (Ngalah) Pasuruan, sekolah ini memiliki tiga jurusan peminatan yang dapat dipilih oleh siswa ketika awal pendaftaran, jurusan tersebut antaralain: 1) Ilmu-Ilmu Sosial (IIS), 2) Ilmu Bahasa dan Budaya (IBB), 3) Matematika dan Ilmu Alam (MIA), selain itu bangunan serta penataan ruang yang dirancang seefektif mungkin, ruang kelas yang memadai dan ruang pendukung lainnya seperti laboratorium, perpustakaan, UKS, ruang BK telah tersedia di sekolah ini. Berdasarkan observasi sekolah ini memiliki dua orang Guru bimbingan dan konseling yang selalu siap untuk menangani berbagai permasalahan siswa.

Guru BK merupakan agen pendidikan yang berfungsi sebagai sebagai konselor di sekolah untuk membatu siswa dalam memecahkan suatu permasalahan. Pada masa pandemi Covid-19, ketika pelaksanaan pembelajaran jarak jauh mulai diterapkan, temuan penelitian terkait peranan guru BK dalam meningkatan motivasi belajar melalui pelayanan bimbingan dan konseling di SMA Darut Taqwa adalah, sebagai berikut:

\section{Memahamkan arti penting belajar/tugas}

Belajar merupakan tahapan perubahan seluruh tingkah laku individu yang relatif menetap sebagai hasil pengalaman dan interaksi dengan lingkungan yang melibatkan proses kognitif. ${ }^{20}$ Melalui proses belajar maka secara bebas setiap siswa akan dapat mengeksplorasi, memilih, dan menetapkan keputusan-keputusan penting untuk kehidupannya. Berdasarkan hal tersebut siswa diberikan pemahaman bahwa belajar mempunyai arti penting dalam kehidupannya di masa mendatang. Karena tidak semua siswa memahami arti pentingnya belajar, apalagi ketika sistem daring mulai

20 Syah, Muhibin. (1999). Psikologis Belajar, Jakarta: PT Logos Wacana Ilmu.hlm.64. 


\section{Al-Isyrof \\ Jurnal Bimbingan Konseling Islam \\ Institut Agama Islam Sunan Kalijogo Malang \\ P-ISSN 2622-674X / E-ISSN 2721-9585 \\ Volume 2, Nomer 1 / Juni 2020}

diterapkan, interaksi antara guru dan siswa mulai berkurang drastis. Untuk itulah pemahaman tentang arti pentingnya belajar melalui media apa pun perlu dipahamkan kepada siswa. Di sekolah guru bimbingan dan konseling sangat berperan penting dalam memberikan pemahaman mengenai pentingnya belajar tersebut. Guru konseling memberikan sosialisasi daring tentang pentingnya belajar ini secara daring setiap 2 minggu sekali. Dalam sosialisasi guru BK juga menerima keluhan dan permasalahan siswa berkaitan dengan pembelajaran daring yang telah dilakukan, tujuan dari sosialisasi pentingnya belajar ini untuk menjaga motivasi dan minat siswa untuk tetap bersekolah meskipun secara daring.

\section{Meningkatkan Kemauan Siswa untuk Melaksanakan Pembelajaran}

Setiap siswa dalam melaksanakan daring membutuhkan suatu media aplikasi yang digunakan untuk pelaksanaan pembelajaran, agar pembelajaran ini dapat terlaksana dengan baik adalah dengan memahami setiap fitur yang ada pada aplikasi tersebut. Beberapa aplikasi yang digunakan dalam pembelajaran di SMA Darut Taqwa yaitu: 1) Zoom, 2) Google classroom dan 3) Google classrom. Namun mayoritas guru banyak yang memanfaatkan google classroom dalam pembelajaran karena aplikasi ini memiliki tampilan yang sederhana dan mudah digunakan. Para siswa pun juga dengan mudah dapat menggunakan aplikasi ini ketika melaksanakan ujian akhir semester.

Pelaksanaan pembelajaran daring ini secara otomatis memberikan dampak menurunnya kemauan siswa dalam melaksanakan pembelajaran, hal ini disebabkan karena mayoritas siswa menganggap pembelajaran daring adalah pembelajaran abstrak sebab tidak adanya interaksi langsung antara guru dan siswa. Untuk itulah peranan guru BK dalam permasalahan ini melakukan beberapa langkah yaitu:

1) Bekerja sama dengan guru wali kelas dan mata pelajaran untuk menganalisis tingkat kehadiran siswa serta perubahan hasil belajar siswa.

2) Memberikan motivasi secara berkala melalui pembelajaran daring, agar siswa tetap konsisten dalam melaksanakan pembelajaran. 


\section{Al-Isyrof \\ Jurnal Bimbingan Konseling Islam \\ Institut Agama Islam Sunan Kalijogo Malang \\ P-ISSN 2622-674X / E-ISSN 2721-9585 \\ Volume 2, Nomer 1 / Juni 2020}

\section{Mengubah pola sistem belajar}

Agar mendapatkan hasil pembelajaran yang maksimal, maka guru BK dengan guru lainnya yang berwenang melakukan pola sistem belajar dengan tujuan untuk menjaga hasil prestasi siswa. Pola sistem belajar online membutuhkan konsistensi dan perhatian yang lebih, untuk itu pembatasan pemberian tugas dan materi dilakukan, pembinaan dan pemberian motivasi dilakukan di saat pembelajaran untuk menjaga tingkat belajar siswa agar selalu konsisten meskipun dilaksanakan secara online.

\section{Menerapkan Metode Belajar}

Guru bimbingan dan konseling selalu memberi informasi cara belajar yang efektif terhadap seluruh siswa, yaitu berkaitan dengan cara menghafal, membaca dan mencatat. Hal ini dilakukan guna melatih siswa agar mereka lebih mudah memahami dan mengetahui cara belajar yang benar ketika pembelajaran daring. Hal ini diimplementasikan untuk mengganti peranan interaksi langsung dari guru yang tidak dapat dilaksanakan secara daring. Hal lain yang dilakukan oleh guru BK yakni secara berkala memberi link-link komunitas belajar gratis baik dari pemerintah maupun non pemerintah, sehingga siswa mendapatkan bisa mendapatkan alternatif lain untuk mengikuti atau menanyakan permasalahan kepada komunitas belajar tentang berbagai permasalahan belajar. Sebab melalui pemanfaatan internet para siswa dapa memperoleh berbagai sumber belajar atau komuitas belajar lebih luas lagi.

\section{Cara mengorganisasi materi pelajaran dan cara menghadapi ujian.}

Guru bimbingan dan konseling juga memiliki peranan dalam membantu siswa mengorganisasi materi pelajaran dan cara menghadapi ujian akhir. Cara yang dilakukan guru BK adalah secara berkala selalu mengingatkan para siswa untuk memiliki materi pelajaran yang akan diujikan, mengingatkan anak-anak tentang jadwal ujian, memberikan informasi tips-tips menghadapi ujian diantaranya harus menjaga kesehatan, menyiapkan materi ujian, dan mengurangi kegiatan-kegiatan yang tidak bermanfaat bagi mereka. 


\section{Al-Isyrof \\ Jurnal Bimbingan Konseling Islam \\ Institut Agama Islam Sunan Kalijogo Malang \\ P-ISSN 2622-674X / E-ISSN 2721-9585 \\ Volume 2, Nomer 1 / Juni 2020}

\section{Meningkatkan Metakognitif Siswa}

Guru bimbingan dan konseling di SMA Darut Taqwa dalam meningkatkan kesadaran metakognitif para siswa adalah dengan cara memberi contoh inspirasi orang-orang sukses yang berkaitan dengan program jurusan yang telah mereka pilih yaitu: 1) IIS, 2)MIA dan 3) IBB. Cara ini diterapkan supaya siswa mau berpikir dan bekerja keras untuk masa depan mereka. Pemberian motivasi tokoh sukses ini diberikan melalui media daring baik dalam bentuk bacaan maupun audio visual seperti film. Selain itu cara guru bimbingan dan konseling SMA Darut Taqwa juga membantu dan membina siswa dalam menentukan pola belajar sesuai dengan kendala dan permasalahan yang dihadapi oleh siswa, siswa diberikan kesempatan secara khusus untuk menyampaikan permasalahannya secara tertulis kepada guru BK, dan secara personal guru BK akan berusaha memberikan solusi kepada siswa tersebut, dengan harapan para siswa tidak kehilangan minat dan motivasi belajar meskipun secara daring.

\section{Mengembangkan Gaya Belajar}

Setiap siswa memiliki gaya belajar yang berbeda-beda, di SMA Darut Taqwa secara umum melalui analisis yang telah dilakukan, ditemukan beberapa bentuk gaya belajar siswa yaitu: 1) gaya belajar siswa yang cenderung visual dan 2) gaya belajar siswa cenderung mempunyai gaya belajar yang auditorial. Sehingga penggunaan gaya belajar ini berpengaruh pada tingkat keberhasilan belajar siswa yang berbeda-beda. Dalam permasalah ini, peran guru Bimbingan dan Konseling akan menganalisis secara keseluruhan mengenai permasalahan gaya belajar siswa. Langkah yang dilakukan adalah dengan cara memfasilitasi dan mengenalkan berbagai ragam gaya belajar kepada siswa. Guru Bimbingan dan Konseling SMA Darut Taqwa mengadakan ssialisasi secara daring kepada siswa tetang berbagai bentuk gaya belajar, tujuannya agar mereka mengenal berbagai gaya belajar yang dapat disesuaikan dengan kondisi pembelajaran daring yang telah dilaksanakan. 


\section{Al-Isurof \\ Jurnal Bimbingan Konseling Islam}

Institut Agama Islam Sunan Kalijogo Malang

P-ISSN 2622-674X / E-ISSN 2721-9585

Volume 2, Nomer 1 / Juni 2020

\section{E. PENUTUP}

\section{Kesimpulan}

SMK Darut Taqwa Pasuruan merupakan lembaga pendidikan formal yang berlatar belakang pondok pesantren, sekolah ini berada dalam naungan Pondok Pesantren Darut Taqwa (Ngalah). Berdasarkan hasil penelitian yang dilakukan, maka dapat diketahui dengan munculnya pandemi covid-19 di Indonesia, secara langsung juga mengubah sistem pembelajaran di SMA Darut Taqwa, maka itu peranan guru BK sangat dibutuhkan selama proses pelaksanaan pembelajaran daring. Peran yang dilakukan oleh guru BK dalam meningkatkan motivasi belajar siswa di SMA Darut Taqwa antara lain: 1) memahamkan arti penting belajar dan tugas terhadap siswa agar dapat melakukan perubahan tingkah laku, 2) meningkatkan kemauan siswa untuk melaksanakan pembelajaranperan guru bk sangat terkait dengan peningkatan motivasi belajar siswa, 3) mengubah pola sistem belajar, 4) menerapkan metode belajar, 5) mengorganisasi materi pelajaran dan cara menghadapi ujian, 6) meningkatkan metakognitif siswa, dan 7) mengembangkan gaya belajar.

Berbagai langkah ini diterapkan oleh guru BK di SMA Darut Taqwa dengan tujuan untuk menjaga motivasi belajar siswa agar tetap konsisten dan tidak menurun akibat perubahan sistem pembelajaran daring yang dilaksanakan sesuai dengan kebijakan pemerintah. Peranan guru BK ini menjadi salah satu upaya sekolah untuk mencapai tujuan belajar dan tetap mempertahankan prestasi belajar di tengah permasalahan munculnya pandemi covid-19 yang mempengarui berbagai aspek kehidupan masyarakat Indonesia. 


\section{DAFTAR PUSTAKA}

A. Black, James \& Dean J. Champion. (2009). Methodes And Issues In Social Research. Terj. E. Koswara, Dira Salam dan Alfin Ruzhendri. Bandung: Rafika Adiatama.

A.M, Sardiman. (2007). Interaksi dan Motivasi Belajar Mengajar, Jakarta:PT Raja Grafindo Persada.

Furchan, Arif. (2005). Pengantar Penelitian dalam Pendidikan. Yogyakarta: Pustaka Pelajar.

Hasbullah. (2005). Dasar-dasar Ilmu Pendidikan, Jakarta: Raja Grafindo Persada.

Juntika, Ahmad. (2006). Bimbingan dan Konseling dalam Berbagai Latar Kehidupan. Bandung: PT. Ravika Aditama.

Lumongga Lubis, Lamora. (2011). Memahami Dasar-dasar Konseling dalam Teori dan Praktik. Jakarta: Prenada Media Group.

Ramayulis dan Mulyadi. (2016). Bimbingan dan Konseling Islam, Jakarta: Kalam Mulia.

S. Winkel, W. (2006). Bimbingan dan Konseling Di Instituti Pendidikan, Yogyakarta:Media Abadi.

Slameto. (2010). Belajar dan Faktor-Fakror yang Mempengaruhinya, Jakarta: Rineka Cipta.

Sugiyono. (2016). Metode Penelitian Kuantitatif, Kualitatif, dan R\&D, Bandung: Alfabeta.

Syah, Muhibin. (1999). Psikologis Belajar, Jakarta: PT Logos Wacana Ilmu.

Tohirin, Bimbingan dan Konseling di Sekolah dan di Madrasah. Jakarta: PT Raja Grapindo Persada.

Uno, Hamzah B. (2011). Teori Motivasi \& Pengukurannya. Jakarta:PT. Bumi Aksara. 